\title{
Triple fixed point theorems for mixed monotone Prešić-Kannan and Prešić-Chatterjea mappings in partially ordered metric spaces
}

\section{MĂdĂLina PĂCURAR ${ }^{1}$, VAsile Berinde ${ }^{2,3}$ MARIN BORCUt $^{2}$ and MiHaela Petric ${ }^{2}$}

\section{ABSTRACT.}

The aim of this paper is to extend the Kannan fixed point theorem from single-valued self mappings $T: X \rightarrow X$ to mappings $F: X^{3} \rightarrow X$ satisfying a Prešić-Kannan type contractive condition:

$$
\begin{gathered}
d(F(x, y, z), F(y, z, u)) \leq \frac{k}{8}[d(x, F(x, y, z))+d(y, F(y, x, y))+ \\
+d(z, F(z, y, x))+d(y, F(y, z, u))+d(z, F(z, y, z))+d(u, F(u, z, y))],
\end{gathered}
$$

or a Prešić-Chatterjea type contractive condition:

$$
\begin{gathered}
d(F(x, y, z), F(y, z, u)) \leq \frac{k}{8}[d(x, F(y, z, u))+d(y, F(z, y, z))+ \\
+d(z, F(u, z, y))+d(y, F(x, y, z))+d(z, F(y, x, y))+d(u, F(z, y, x))] .
\end{gathered}
$$

The obtained tripled fixed point theorems extend and unify several related results in literature.

Acknowledgements. The paper has been finalized during the visit of the first two authors to Department of Mathematics, Universita di Roma Tre. They gratefully thank Professor Andrea Laforgia for kind hospitality and excellent work facilities offered.

The research was supported by the Grant PN-II-RU-TE-2011-3-239 of the Romanian Ministry of Education and Research. The second author's research has been partly supported by the Grant PN-II-ID-PCE-2011-3-0087 of the Romanian Ministry of Education and Research.

\section{REFERENCES}

[1] Berinde, V., Iterative Approximation of Fixed Points, Springer, Berlin Heidelberg New York, 2007

[2] Berinde, V., Generalized coupled fixed point theorems for mixed monotone mappings in partially ordered metric spaces, Nonlinear Anal., 74 (2011), No. $18,7347-7355$

[3] Berinde, V., Coupled coincidence point theorems for mixed monotone nonlinear operators, Comput. Math. Appl., 64 (2012), No. 6, 1770-1777

[4] Berinde, V., Coupled fixed point theorems for $\phi$-contractive mixed monotone mappings in partially ordered metric spaces, Nonlinear Anal., 75 (2012), No. 6, 3218-3228

[5] Berinde, V. and Borcut, M., Tripled fixed point theorems for contractive type mappings in partially ordered metric spaces, Nonlinear Anal., 74 (2011), No. 15, 4889-4897

[6] Berinde, V. and Păcurar, M., An iterative method for approximating fixed points of Prešić nonexpansive mappings, Rev. d'Anal. Numer. Theor. Approx., 38 (2009), No. 2, 144-153

[7] Berinde, V. and Păcurar, M., Two elementary applications of some Prešić type fixed point theorems, Creat. Math. Inform, 20 (2011), No. 1, 32-42

[8] Berinde, V. and Păcurar, M., Coupled fixed point theorems for generalized symmetric Meir-Keeler contractions in ordered metric spaces, Fixed Point Theory Appl, 2012, 2012:115, 11 pp.

[9] Bhaskar, T. Gnana and Lakshmikantham, V., Fixed point theorems in partially ordered metric spaces and applications, Nonlinear Anal., 65 (2006), No. 7, 1379-1393

[10] Bojor, F., Fixed points of Kannan mappings in metric spaces endowed with a graph, An. Ştiinţ. Univ. "Ovidius" Constanţa Ser. Mat., 20 (2012), No. 1, $31-40$

[11] Borcut, M., Tripled fixed point theorems for monotone mappings in partially ordered metric spaces, Carpathian J. Math., 28 (2012), No. 2, 215-222

[12] Borcut, M., Tripled coincidence theorems for monotone mappings in partially ordered metric spaces, Creat. Math. Inform., 21 (2012), No. 2, 135-142

[13] Borcut, M., Tripled coincidence theorems for contractive type mappings in partially ordered metric spaces, Appl. Math. Comput., 218 (2012), No. 14, 7339-7346

[14] Borcut, M. and Berinde, V., Tripled coincidence theorems for contractive type mappings in partially ordered metric spaces, Appl. Math. Comput., 218 (2012), No. 10, 5929-5936

[15] Borcut, M., Păcurar, M. and Berinde, V., Tripled fixed point theorems for mixed monotone Kannan type contractive mappings, J. Appl. Math., 2014, Art. ID 120203, 8 pp.

[16] Chen, Y.-Z., A Prešić type contractive condition and its applications, Nonlinear Anal., 71 (2009), No. 12, e2012-e2017

[17] Chatterjea, S. K., Fixed-point theorems, C. R. Acad. Bulgare Sci., 25 (1972), 727-730

[18] Choudhury, B. S. and Kundu, A., A Kannan-like contraction in partially ordered spaces, Demonstratio Math., 46 (2013), No. 2, $327-334$

[19] Cirić, L. B. and Prešić, S. B., On Prešić type generalization of the Banach contraction mapping principle, Acta Math. Univ. Comenianae, 76 (2007), No. 2, 143-147

[20] Kannan, R., Some results on fixed points, Bull. Calcutta Math. Soc. 10 (1968) 71-76

[21] Karapinar, E. and Berinde, V., Quadruple fixed point theorems for nonlinear contractions in partially ordered metric spaces, Banach J. Math. Anal., 6 (2012), No. 1, 74-89 
[22] Păcurar, M., Approximating common fixed points of Prešić-Kannan type operators by a multi-step iterative method, An. Ştiinţ,. Univ. "Ovidius" Constanţa Ser. Mat.,17 (2009), No. 1, 153-168

[23] Păcurar, M., Iterative Methods for Fixed Point Approximation, Risoprint, Cluj-Napoca, 2010

[24] Păcurar, M., A multi-step iterative method for approximating fixed points of Prešić-Kannan operators, Acta Math. Univ. Comen. New Ser., 79 (2010), No. $1,77-88$

[25] Păcurar, M., A multi-step iterative method for approximating common fixed points of Prešić-Rus type operators on metric spaces, Stud. Univ. BabeşBolyai Math., 55 (2010), No. 1, 149-162

[26] Păcurar, M., Fixed points of almost Prešić operators by a k-step iterative method, An. Ştiint,. Univ. Al. I. Cuza Iaşi, Ser. Noua, Mat., 57 (2011), Supliment 199-210

[27] Păvăloiu, I., Rezolvarea ecuaţiilor prin interpolare, Editura Dacia, Cluj-Napoca, 1981

[28] Păvăloiu, I. and Pop, N., Interpolare şi aplicaţii, Risoprint, Cluj-Napoca, 2005

[29] Petric, M., Some results concerning cyclical contractive mappings, Gen. Math. 18 (2010), No. 4, 213-226

[30] Petric, M., Best proximity point theorems for weak cyclic Kannan contractions. Filomat 25 (2011), No. 1, 145-154

[31] Petric, M. and Zlatanov, B., Best proximity points and fixed points for p-summing maps. Fixed Point Theory Appl. 2012, 2012: 86, 12 pp.

[32] Prešić, S. B., Sur une classe d' inéquations aux différences finites et sur la convergence de certaines suites, Publ. Inst. Math. (Beograd)(N.S.), 5 (19) (1965), 75-78

[33] Rus, I. A., An iterative method for the solution of the equation $x=f(x, \ldots, x)$, Rev. Anal. Numer. Theor. Approx., 10 (1981), No.1, $95-100$

[34] Zamfirescu, T., Fix point theorems in metric spaces, Arch. Math. (Basel), 23 (1972), 292-298

${ }^{1}$ Department of Statistics, Forecast and Mathematics

"BABEŞ-BOLYAI" UNIVERSITY OF ClUJ-NAPOCA

T. MiHali 58-60, 400591 Cluj-NAPOCA, ROMANiA

E-mail address: madalina.pacurareecon.ubbcluj.ro

2 Department of Mathematics and Computer Science

NORTH UNIVERSITY CENTER AT BAIA MARE

TECHNICAL UNIVERSITY OF CLUJ-NAPOCA

VICTORIEI 76, 430122 BAIA MARE ROMANIA

E-mail address: vberinde@ubm.ro; marinborcut@yahoo.com; petricmihaela@yahoo.com

${ }^{3}$ Department of Mathematics and Statistics

King Fahd University of Petroleum AND Minerals

DHAHRAN, SAUDI ARABIA

E-mail address: vasile.berinde@gmail.com 